\title{
Identification of Academic Culture Dimensions in Entrepreneurship Learning at Universities in Central Java
}

\author{
Susilaningsih ${ }^{1}$, Siswandari $^{1}$ \\ ${ }^{1}$ Sebelas Maret University, Jl. Ir. Sutami 36 A Surakarta, Indonesia \\ susi_uns@yahoo.com
}

\begin{abstract}
This study aims to identify academic culture in entrepreneurship education. Therefore, its result can be used for improving entrepreneurial learning process at universities as to grow an entrepreneurial culture. In long-term, the growth of entrepreneurial culture among students is indirectly expected to have an effect on the reduction of the unemployment rate coming from higher education graduates and the improvement of economic growth significantly.

This research utilized the survey approach with multistage random sampling. Descriptive qualitative was used to analyze the data. The result of the study on the four dimensions of academic culture, which refer to entrepreneurial culture, is as follows: Most students (80\%) have a low Power Distance dimension, a relatively low Certainty Avoidance dimension, a relatively high Individualism- Collectivism dimension; and a considerably low Masculinity- Femininity.
\end{abstract}

\section{Keywords: academic culture; entrepreneurial culture; entrepreneurial learning}

\section{INTRODUCTION}

Culture as shared behavior and shared human-made aspects of society includes practices and values [26]. It also encompasses value system, attitude, belief, and behavior related to the surrounding environment context [1]. This culture can be transmitted and learned by the society including campus community. One of the results of researches on culture is the one developed by Hofstede [2]. There are five dimensions of culture which have been utilized by more than 50 countries in the world in order to develop the cultural variations of each country which is studied. Four of which are suitable to be developed in Indonesia to be integrated with the entrepreneurial culture so that university graduates who are expected to be new entrepreneurs have a better entrepreneurial culture. The four dimensions are power-distance, uncertaintyavoidance; individualism-collectivism; and masculinity-feminity. The positive side development of the four dimensions should be one of the references for Indonesian students to improve self-quality so that they will be more prosperous after they have graduated [3-5], until finally they are convinced that becoming a new entrepreneur is a logic and appropriate career choice. 


\section{LITERATURE REVIEW}

\section{Academic Culture}

Culture has been defined differently, depending on the points of view used. Culture is defined as behaviors that are transmitted and aspects which are created by human beings and which are then transmitted to communities. The culture encompasses practices and values [1]. This is in line with the claim of Thomas (2008) who stated that culture is organized value system, attitude, belief and meaning of behaviors which are interrelated and which are related to environmental context. Culture can be transmitted and learned by those of communities in addition to its organized and systematic characteristics. Hofstede (2001) defined culture as the programming of collective thoughts, which differentiates the members of one community from those of other communities [2].

Kluckhohn and Strodtbeck as quoted by Thomas (2008) identified six dimensions of culture found in society [6]. Firstly, in connection with nature, human beings probably tend to dominate, conquer, or harmonize. Secondly, in relation to belief about the nature of beings, human beings can become good, evil, or a combination of both. Thirdly, regarding other human beings, one tends to individualistic, equal, or hierarchical. Fourthly, with regard to human activities, people focus their attention on being, striving to achieve their goals, or doing self-reflection (thinking). Fifthly, concerning space, there are public, private, or a combination of both spaces. Sixthly, on the subject of time orientation, people probably appreciate past events, current events, or future events. Based on those dimensions, society of a state can show patterns, which are represented by certain values of each dimension.

Hofstede (2001) classified the cultural dimensions which differentiate the culture between countries into five categories, namely: individualism-collectivism, power distance, uncertainty avoidance, masculinity-feminity, and long term - short term orientation [2]. Power distance is to what extent the difference of power is accepted (who is more capable, wiser, more powerful, and usually more respected due to his or her power) and understood to give sanctions in society. Uncertainty avoidance is a way of society declines, reduces, or minimizes uncertainty and creates stability. Individualism-collectivism is related to characteristics of an individual in self-reflection whether he or she is a part of a group or individualistic. Masculinity-feminity is related to traditional orientation that males are more emphasized to have ambitions and achievements than females who are hereditarily believed to bear parenting and interpersonal harmonization assignments. Long term - short term orientation is related to how someone is oriented toward the future for a long term whereas for short term how someone addresses the past and the present such as respecting traditions and carrying out obligations in society. The four dimensions (except long term-short term orientation) have been used to identify cultural differences in more than 50 countries through giving the scores of 1-100 for each dimension [2].

In relation with the management of an institution, culture apparently affect an organization and becomes an identity of the people in the organization [7], either in educational organization, in business organization, or in industrial organization. It also affects the management-style of top leaders. In human resource management practices, culture plays an important role because it characterizes the policies and decisions taken by the top leaders [7-8]. 


\section{The Importance of Entrepreneurship Education To Improve Entrepreneurial Culture}

University is an institution which is well-known to have special, unique, specific and even exclusive academic tradition and culture. The most valuable non-tangible assets of a university are freedom, autonomy, and academic culture that it bears. In this case, the university must have special characteristics which become good examples for a wider society. One of good examples is when there are many graduates having entrepreneurial spirit [9] and also be able to help government to establish their own work such as become an entrepreneur [3]. To implement this idea it is a must for university to develop entrepreneurial learning [10] in order to enhance better academic culture [11]. However it is not simply work to conduct since Entrepreneurship education programs are not homogeneous, when the entrepreneurship education program is the same but the different teacher would give the different impact to the students. This is contrast with the research result from Karimi et.al (2014) who claimed the entrepreneurship education programs had significant positive impact to the student behavior.

Academic culture which characterizes a university plays an important role in building and developing culture and civilizations of a nation as a whole. The indicators for university's quality are determined among others by quality of academic community and graduates who continuously participate in building and developing better civilizations of the nation. High civilizations among others are characterized by autonomy of a nation. Such autonomy can commence from the meaningful entrepreneurship learning [9, 12-13].

\section{METHODOLOGY}

Research method is a way that can be used by a researcher in order to perform his or her research [14-15]. This research used the qualitative research approach [16. It was chosen as the researchers were willing to describe things factually when the research was being conducted. The description was done thoroughly, in depth, and completely. The survey was carried out to gain information by deeply observe the students in entrepreneurship education classes in order to identify four cultural dimensions proposed by Hofstede (2001) [2]. Hofstede (2001) identify three group of society at large, they were (1) in the Family, (2) At School, and (3) in the Work Organization. In this reseach, the information about four cultural dimensions was collected from Hofstede's questionnaire related to 'At School' since the unit of analysis was the higher education student. Adopted statements from four cultural dimensions was Power Distance dimension (2001: 107), Certainty Avoidance dimension (2001:169), Individualism- Collectivism dimension (2001: 237), and Masculinity- Femininity (2001: 306). For each statement of these four dimensions was giving the scores from 1 to 10 .

Using the descriptive analysis, the researchers intended to study meanings and contexts of behaviors and processes taking place in interrelation patterns of various factors observed. Through the multistage-random sampling, 400 students of Sebelas Maret University (UNS) and Diponegoro University (UNDIP) were determined as the samples of the research. The procedure of drawing sample is as follows, (1) Determine 
state universities at Central Java and choose two of them randomly (2) select ten study program from those two universities to observe and (3) select 400 students from those ten study program randomly.

The exploration toward the four dimensions of academic culture in this research was performed by using validated and reliable research instruments. Content validity was used to test the validity while alpha cronbach was used to assess reliability. The validity range was $0.615-0.812$ and the coefficient of alpha Cronbach was 0.877

\section{RESULT}

The results of the explorative study show that the dimensions of academic culture which support the development of entrepreneurship learning among the university students are as follows:

TABLE 1. AVERAGE SCORE OF FOUR CULTURAL DIMENSIONS

TABLE 1. AVERAGE SCORE OF FOUR CULTURAL DIMENSIONS
\begin{tabular}{|l|l|l|l|l|}
\hline & PD & UA & IC & MF \\
\hline Mean $(\mathrm{X})^{-}$ & 4.336 & 3.600 & 8.300 & 4.000 \\
\hline Variance $\left(\mathrm{S}^{2}\right)$ & 0.2045 & 0.212 & 0.138 & 0.082 \\
\hline
\end{tabular}
PD: Power Distance UA: Uncertainty Avoidance IC: Individualism-Collectivism MF: Masculinity-Feminity

TABLE 2. THE CRITERIA OF LEVELING FOR EACH DIMENSION

\begin{tabular}{|l|l|}
\hline Average Score & Level \\
\hline$>8.0$ & High \\
\hline $6.0-8.0$ & Moderate \\
\hline$<6.0$ & Low \\
\hline
\end{tabular}

The students of UNS and UNDIP generally have a low Power Distance characteristic wtih average score 4.336. It means they do not agree to the phenomenon that those who are regarded as more capable, wiser, and more powerful can freely give sanctions and rules at their own will to less capable and less powerful communities. The students highly appreciate seniority but feel others as their friends or colleagues, neither as an ordinate and a sub-ordinate nor as a father and children.

This characteristic can generate a positive effect on the development of entrepreneurial culture where a new entrepreneur not only own such entrepreneurial characteristics as high-achieving, collaborative, competitive, hardworking, unyielding, confident, willing to bear risks, very appreciative of others, appreciative of time, appreciative of money, creative, innovative, good at capturing business opportunities, good at performing locus of control [9]. In addition, they also have a seniorityrespecting culture, but disagree if the more senior ones act arbitrarily against others although they are more capable and more powerful due to their abundant precious treasure.

The low power distance means there is no distance between students and their teachers/lecturers. The students can openly communicate with their teachers. The students more active in learning and they are able to learn by themselves. 
The students of UNS and UNDIP generally have a low Uncertainty Avoidance with the average score 3.6. It indicates that they tend to do innovations, and they dare to take risks. Such characteristics are good for the development of entrepreneurial culture where an entrepreneur must be responsible for something which is a consequence for anything he or she has done. Performing low for uncertainty avoidance can be considered as a very good condition [2] because if students have a high level of uncertainty avoidance, they tend to be worry and stressed for their ambiguous future [17].

The students of UNS and UNDIP in general have a relatively high IndividualismCollectivism characteristic. The average score is 8.3 for individualism-collectivism. it points out that their dependence on others is relatively low. Such a characteristic is good for the development of entrepreneurial culture. An entrepreneur must be autonomous, not relying on the power of others. Their sense of responsibilities toward their work result has been good. They do not rely on the result of group work. Even, they are able to work individually to support the result of group work. The students also dare to assert themselves, and they are willing to show themselves as the originators of ideas, drafters, etc. In addition, the high of individualism-collectivism means teacher deals with individual pupils, pupils' individual initiatives encourage, students report "modern" views, and students expected to speak up in class or large group.

The students of UNS and UNDIP have a low Masculinity-Feminity characteristic in general. They acknowledge gender equality. They claim that females also have opportunities for advancement. This characteristic is good for entrepreneurial development culture in which males view businesswomen well. Females should also be given opportunities to be entrepreneurs. Thus, in general the four dimensions of academic culture among the students can be developed further. For examples, the four dimensions are integrated into the entrepreneurship learning appropriately.

The interesting result of this research is that female students have a higher autonomy than male ones. They have a spirit to attain on their own, and they are not dependent males. Thus, it can be said that there should not be any gender difference in the development of entrepreneurship learning at universities to create potential new entrepreneurs. The students view that males should not be seen to be more dominant and to have more achievements than females who are hereditarily thought to bear parenting and interpersonal harmonization assignments.

These four cultural dimensions should be developed during entrepreneurship teaching learning process with applied-hands on activities [18] to possibly prepare better opportunity [19] and strengthen the students entrepreneurial culture since the practical of teaching techniques significantly contributes the students in the future especially in their entrepreneurial organizations [20]. By equipping students with four cultural dimension combined with experiential learning in entrepreneurship education [18] would tend to reduce management conflict in the future work place [21].

\section{CONCLUSION}

The role of this current study is clearly tended to improve the entrepreneurial learning process in order to enhance the future students' entrepreneurial culture. Equipping the students with good culture is really important since it will shape their personality. Better culture would affect the students' performance in their live after 
graduation. Since the portraits of the four dimensions of students' academic culture are as follows: (1) the students have a low Power Distance, (2) their Uncertainty Avoidance dimension is also low, (3) their Individualism Collectivism is relatively high, and (4) their Masculinity-Feminity dimension is considerably low, one could expect that the university graduate would have better behaviour in the future, especially when they become a new entrepreneur.

\section{REFERENCES}

[1] Triandis, H.C and S.A. Wasti. (2008). Culture - The Influence of Culture on Human Resource Management Processes and Practices. New York: DL Stone and EF Stone - Romero

[2] Hofstede, G. (2007). Cultural Constraint in Management Theories: The Influence of Culture in the World of Business. M. B. Hinner. Frankfurt, Peter lang.

[3] McLarty, R. (2005). Entrepreneurship among Graduates: Towards a Measured Response. Journal of Management Development. 24(3), 223 - 238

[4] Fawcett, E, G.K.Rhoads \& P. Burnah. (2004). People as the Bridge to Competitiveness. Benchmarking-an International Journal. 11(4), $346-360$.

[5] Offstein, E. H. et.al. (2004). Are We Doing Enough for Today's Graduate Student? The International Journal of Educational Management. 18(7), 396 - 407

[6] Thomas, D. C. (2008). Cross Cultural Management: Essential Concepts. Los Angeles: SAGE.

[7] Robbins, S.P \& M. Coulter. (2004). Management. 7th Ed. Pearson Education, UpperSaddleRiver: Prentice-Hall International Inc. Indonesian Language Edition, PT Indeks Kelompok GRAMEDIA

[8] Robbins, S.P. (2003). Organizational Behavior.10th Edition. Pearson Education, Upper Saddle River: Prentice-Hall International Inc.

[9] Susilaningsih (A). 2015. Pendidikan Kewirausahaan di Perguruan Tinggi: Pentingkah untuk Semua Profesi? Jurnal Economia: Kajian Ilmiah Ekonomi \& Bisnis, ISSN: 1858-2648. 11 (1), $1-9$

[10] Heinonen, J. \& Hytti, U. (2010). Back To Basics: The Role Of Teaching In Developing The Entrepreneurial University. The International Journal of Entrepreneurship and Innovation. 11, $283-292$.

[11] Lackeus, M. (2015). Entrepreneurship in education. European Comission.

[12] (B). (2015). Generic Entrepreneurship Education Program Design At Universities. Proceeding. 2nd International Conference on 'GLOBAL TRENDS IN ACADEMIC RESEARCH' (GTAR-2015).ISBN:978-969-9948-12-1, pp. 20

[13] (C). (2012). Continuing Model of Higher Education Entrepreneurship Program in Indonesia. E-Proceeding 8th Biennial Conference of the Comparative Education Society of Asia (CESA) on Education at the Dawn of the New Decade: When the Quality and Sustainability Movements Converge. The Faculty of Education, Chulalongkorn University,Bangkok Thailand

[14] Babbie.E.R. (1975). Practice Of Social Research. California: Wadswoth Publishing.

[15] Dominowski. (1980). Research Methods, Englewood Cliffs: Prentice-Hall Inc

[16] Johnson, B and L.Christensen. (2004). Educational Research - Quantitative, Qualitative, and Mixed Approach. 2nd Ed.New York: Pearson Education Inc.

[17] Yildirim. Emre and Barutcu. M.T. (2016). How Uncertainty Avoidance, Power Distance and Indulgence Affect Social Commerce Expenditure? An Investigation Based on Facebook. International Journal of Science Culture and Sport. 4(4), $404-421$

[18] Honig. Benson. (2004). Entrepreneurship Education: Toward a Model of Contingency-Based Business

Planning. Journal of Academy of Management Learning and Education. 3(3), 258-273

[19] Antoncic. Bostjan and Hisrich. Robert D. (2003). Clarifying the Intrapreneurship Concept. Journal of Small Business and Enterprise Development. 10(1), 7-24 
[20] Robinson. David F. (2008). Planting The Seeds Of Effective Entrepreneurship By Teaching Risk, Advising, And Design Through Growth. Journal of Technology, Management \& Innovation. 3(1), 29-35

[21] Purohit. Yasmin S, and Simmers. Claire A. (2006). Power Distance and Uncertainty Avoidance: A Cross-National Examination of Their Impact on Conflict Management Modes. Journal of International Business Research. 5(1), $1-9$

[22] Ary, D, Lucy C.J \& Asghar R. (2002). Introduction to Research in Education. Belmont: Wadsworth Thompson Learning

[23] Borg, W.R\& Meredith D Gall. (2011). Educational Research - An Introduction. 4th Ed.

[24] Bruyat, C. \& Julien, P.-A. (2001). Defining the field of research in entrepreneurship. Journal of Business Venturing, 16, 165-180.

[25] (2001). Culture Consequences: Comparing values, Behaviour, Institution and Organisations Across Nations. Thousand Oaks: Sage Publication.

[26] Instruction of President of The Republic of Indonesia Number 4 of 1995 concerning National Movement to Socialize Civilize Entrepreneurship Dated, June 30th, 1995

[27] Krajewski, L.J \& Larry P. Ritzman. (2002). Operation Management - Strategy and Analysis 6thEd.UpperSadleRiver: Prentice-Hall International Inc. 